\title{
A Resource of Resources for STEM Educators
}

\author{
Review of: Teaching and Learning STEM: A Practical Guide, by Richard M. Felder and \\ Rebecca Brent, with a foreword by Barbara Oakley; 2016; 336 pp.; Jossey-Bass (San \\ Francisco); ISBN: 978-1-118-92581-2 (hardcover edition)
}

Reviewed by Cheryl A. Sensibaugh*, Department of Biochemistry and Molecular Biology, University of Georgia, Athens, GA 30602

$\mathrm{H}$ ave you been wondering how to successfully implement group work? Or what to do to dramatically reduce student resistance when students become the ones who are primarily accountable for their learning? Concrete, practical solutions to these and many, many more questions are found in Teaching and Learning STEM. To answer such questions before publication of this resource, educators were required to interpret and apply pedagogical principles such as scientific teaching (Handelsman et al., 2004, 2006) and backward design (Wiggins and McTighe, 2005), which added to the workload of improving courses. Additionally, practical advice about active learning had to be obtained by scouring the literature, networking with master educators, and/ or identifying and garnering the resources to attend teaching development workshops such as the Summer Institutes (Yale Center for Teaching and Learning, 2016). Perhaps a few reading this review were even lucky enough to take part in a seminar offered by Felder and Brent.

This book is, to date, the ultimate guide for designing courses in a manner that takes advantage of the ways students learn best. The evidence-based methods compiled and communicated accessibly in this volume have been shown to improve performance across diverse populations of students in science, technology, engineering, and mathematics (STEM) disciplines for many coveted outcomes without loss of coverage of key concepts. Those outcomes include problem-solving skills, professional skills (communication, creative thinking, and self-directed learning), and teamwork skills (cooperativity and resolving conflicts). Rather than overloading students with facts and weakly motivating students with assurances that the importance of those facts will become clear in time, Felder and Brent frame the goal of education as the need to prepare students to be successful STEM professionals or STEM-literate citizens. This guide offers a plethora of techniques and practical advice to apply when educators begin using more learner-centered methods in their courses. Throughout this "metaresource," or resource of resources, we are assured that pedagogical reform is possible. Best practices have emerged from empirical scrutiny, and our own teaching can be improved by considering even small shifts in perspective from traditional teacher-centered methods to proven learner-centered methods.

Indeed, Felder and Brent argue convincingly that change can take place incrementally. These experts advise that it is completely acceptable to venture slowly into unfamiliar waters, which offers solace to wary educators. Even those who are practiced or experts themselves in active learning, flipped classrooms, or group work are sure to benefit by the creative suggestions offered. In my own case, trained as a discipline-based education researcher, I nevertheless extracted two broad benefits. First, while I recognized some of the learner-centered pieces presented in this guide, many were new to me, and it was extremely helpful to see their connections to familiar strategies made explicit. Second, simply by engaging with the authors' perspectives

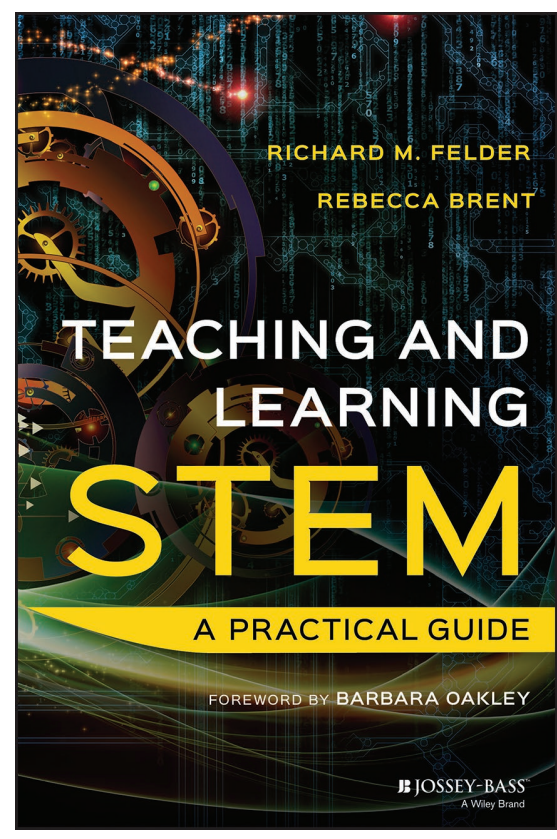

CBE Life Sci Educ December 1, 2016 15:fe8 DOI:10.1187/cbe.16-07-0218

*Address correspondence to: Cheryl A. Sensibaugh (csensiba@uga.edu).

(C) 2016 C. A. Sensibaugh. CBE-Life Sciences Education (c) 2016 The American Society for Cell Biology. This article is distributed by The

American Society for Cell Biology under license from the author(s). It is available to the public under an Attribution-Noncommercial-Share Alike 3.0 Unported Creative Commons License (http://creativecommons.org/licenses/ by-nc-sa/3.0).

"ASCB®" and "The American Society for Cell Biology®" are registered trademarks of The American Society for Cell Biology. 


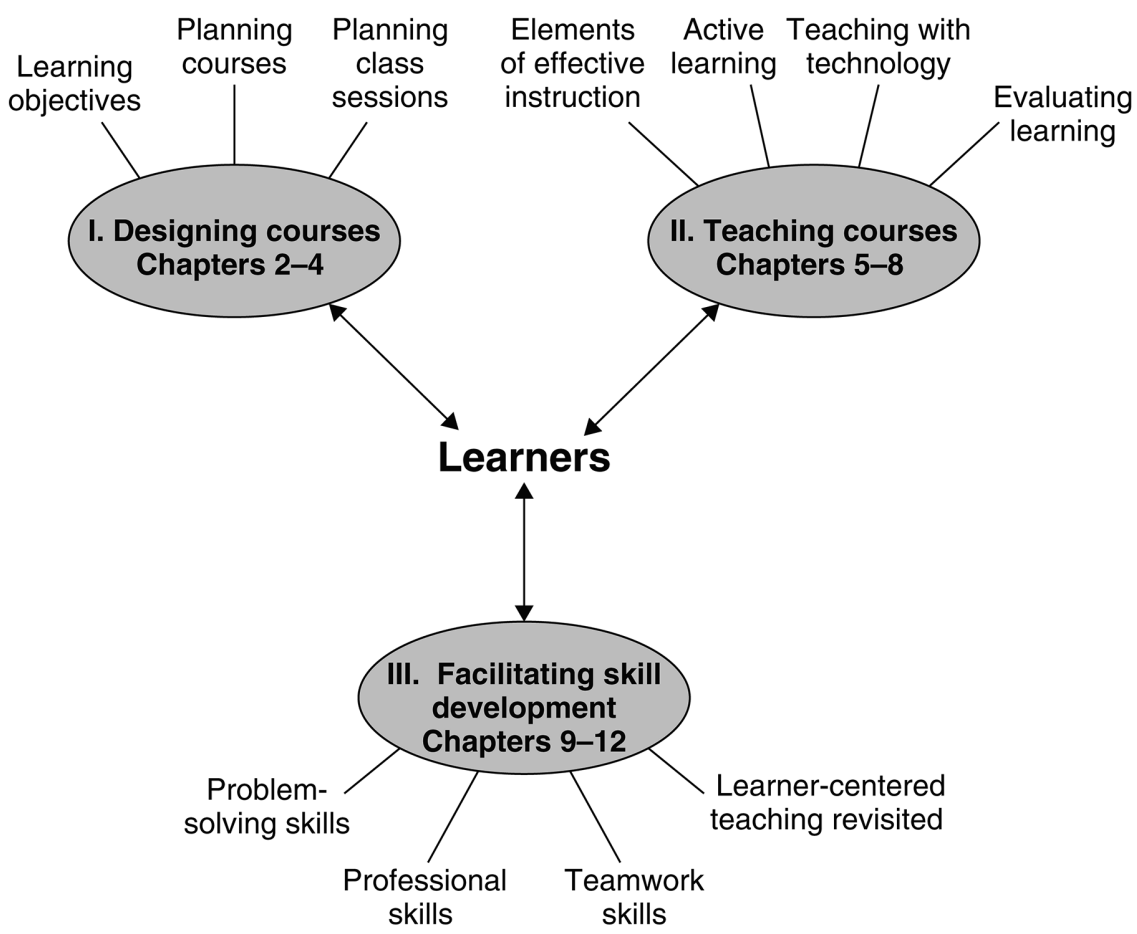

FIGURE 1. The first graphic organizer in the book ("Figure 1.3-1: Elements of Learner-Centered Teaching") summarizes chapter topics (text branches), groups them into three main parts of the book (gray ovals), and emphasizes that learners play the central role around which pedagogy is designed (double-headed arrows). Artwork copyright (c) 2016 by John Wiley \& Sons, Inc.

and following the reasoning they model, I found my own creativity expanding to draw new connections and conceive of even more possible strategies that fit within the learner-centered framework.

\section{MAKING PRACTICAL SENSE OF CHANGE}

To illuminate the need for pedagogical change and make sense of how to go about it, this seminal work combines extensive research findings, theories from cognitive science, and explanations from neuroscience, with realistic recommendations from two respected educators who have devoted their careers to STEM education and faculty development. The result is a work so comprehensive that it may be envisioned not only as a guide for current educators but as a textbook for graduate and undergraduate courses in STEM education and within teaching certificate programs. As an added benefit, its conversational tone makes it extremely easy to read. Barbara Oakley aptly comments in the foreword that "husband-and-wife team Richard Felder and Rebecca Brent write in an exceptionally clear, nonstuffy voice that makes this a book you can read even at the end of a busy day." It will even make you laugh on many occasions. Its accessibility is further enhanced by its format: rather than requiring one to absorb the entire volume in sequence, the authors suggest treating it as a menu. Readers may skim the contents and focus only on what they choose at that particular time. The repetition of themes and cross-referencing that make this use possible are, in turn, tremendous learning aids for others who may desire a complete viewing or who may cover it comprehensively as a textbook.
Teaching and Learning STEM aptly follows its own advice. It examines and rejects the assumption that, for teaching and learning to be successful, mastery of factual knowledge is required before dealing with real-world processes, systems, problems, and challenges. Accordingly, overviews start with educational problems and concerns that are familiar to readers. One example-inevitably faced by every educator-is preparing to teach a new course or making significant revisions to an existing course (p. 41). The need for information is addressed before identifying reasonable chunks that are then deeply explored. In this case, readers need to know how to make the task manageable, so the authors present guiding questions such as "What is a reasonable time to devote to preparing a course?" and "How can I approach that target?" Then, ideas are explored in detail and assembled to make connections with broader goals. To encourage readers to reflect deeply on the process and think about the thought process used to meet the goals of the task, guided opportunities for metacognition are interspersed along the way as "Thought Questions." For instance, when discussing course planning, Felder and Brent direct readers to consider how a course might be strengthened by reducing content that is easy to find or does not directly address learning objectives (p. 46).

Visual representations called "graphic organizers" are recommended at several points within the book. Again, the authors demonstrate their suggestion by presenting their own graphic organizers, one of which maps out the overall contents of the book (Figure 1). Additional graphic organizers detail each of the book's three parts: designing courses (p. 12), teaching courses (p. 90), and facilitating skill development (p. 186).

Before each chapter, interludes serve either as reflective transitions or as scenarios that foreshadow the upcoming topic. These interludes quickly became anticipated favorites, sometimes inspiring laughter, sometimes shock. Within the chapters, snippets labeled "Brainwaves" offer explanations of student learning that are rooted in findings from neuroscience. We scientists find it satisfying to discover more about the science behind the learning of science. Each chapter concludes with the same two sections: "Ideas to Take Away," which is a valuable summary of main points, and "Try This in Your Course," which assembles the key techniques and offers a way to initiate a new strategy through a smaller pilot.

At least one section in each chapter discusses mistakes to avoid, with clear reasons given and preferred alternatives presented, along with evidence to substantiate the recommendations. The authors have truly compiled a resource of resources, from evidentiary articles to Web-based tools, databases of activities, and instructional videos. Most of these resources are embedded throughout the text, in places where they relate to the topic being discussed. In addition, a list of tables, figures, 
and exhibits summarizes the visual elements, and a bibliography and index are also included. To further extend this metaresource, you can even assign students to find additional online resources as a course activity (p. 149).

One of the most impressive resources-deservedly discussed in more depth than most-is the CATME Smarter Teamwork system, available at www.catme.org (Loughry et al., 2007, 2014; Ohland et al., 2012). Access to this suite of teamwork tools is free. One of the tools (Team-Maker) uses criteria, either selected from available options or user defined, to assign students to teams. Other tools (Peer Evaluation and Rater Calibration) are established to facilitate self- and peer evaluations. The remaining modules train students to work in teams and provide guidance on making meetings more effective. Felder and Brent expertly coach readers about the applications of this technology.

Concrete tips for educators are also aimed toward identifying reasonable targets or goals. As mentioned previously, guidelines are offered for how much time to spend on course preparation. For new or entirely redesigned courses, the target is 3 to 4 hours per hour of class time. For subsequent revisions, 2 hours or fewer of preparation should be sufficient for each hour of class (p. 44). Rest assured that techniques are outlined to achieve these targets. Other guidelines address two aspects of assessment: testing higher-order cognition and test length. Felder and Brent advocate that 10 to $20 \%$ of test points should be reserved for measuring higher-order learning objectives such as analyzing, evaluating, and creating (p. 167). The 10\% minimum demonstrates alignment of the assessment with higher-order learning objectives and incentivizes preparation for those tasks. The $20 \%$ maximum is set so that the assessment maintains its ability to distinguish among levels of mastery. When more than $20 \%$ of a test targets higher-order objectives, a score distribution is likely to reveal only two groups of students: those who demonstrate attainment of the higher-order objectives and those who do not. The visual representation of this bimodal score distribution would show one narrow peak in the high range of scores and a broad peak across the low range of scores. The narrow peak would not be able to differentiate between "A" and "B" students, while the peak across low scores would underestimate student knowledge. Neither peak would ultimately be informative about overall student learning and pedagogical practice, aside from the need to reduce the weight upon higher-order objectives to below $20 \%$ of the total points. Regarding test length, the guideline depends upon whether "particularly complex and/or computation-heavy problems are included." If not, allow students test-completion time that is three times as long as it takes instructors and teaching assistants to complete the test. If so, allow students up to five times as much time (p. 169).

Tangible recommendations are also made for promoting metacognition, such as sample questions to include in assignments (p. 207) and "exam wrappers" (p. 171). An exam wrapper is a questionnaire attached to a test when the test is returned to students, prompting students to think about their thinking on that test (i.e., their approach to the test, whether the approach was successful, and changes they might make for the next test). Once again, literature references and an online resource with sample questions are provided. Responding to student resistance is addressed in several areas, with an example scenario provided as one of the interludes (p. 243). Writing strategies are the topic of another interlude (p. 65) and serve equally well for educators writing a lesson plan, students writing a thesis, and researchers writing a manuscript. Finally, educational terms are clarified. For example, what is the difference between assessment and evaluation (p. 62)? Or between inquiry-based learning, problem-based learning, and other inductive teaching methods (Table 12.2-1)? It is also worth mentioning that the book is available from several suppliers (e.g., Amazon, Barnes \& Noble, Google) in both hardcover and electronic versions below list price.

Only one recommendation for improving Teaching and Learning STEM comes to mind. The authors advise soliciting feedback from other educators during the process of course preparation. This advice raised several questions for me: Might it be wise to embark on that course preparation using a truly collaborative approach (i.e., with a partner or group that is simultaneously engaged in the same process), much in the same way that teamwork is detailed for learners of STEM disciplines? Or is there an evidence-based rationale for keeping interactions limited to feedback about certain concerns? What are some considerations to keep in mind if educators do decide to use a simultaneous or collaborative approach? Are there potential pitfalls to avoid? If there are differences between collaborating for educational planning purposes and research purposes, what exactly are those differences?

\section{CONCLUSION}

This excellent resource inspired excitement about what future undergraduate STEM classrooms may look like. Imagine the powerful role that educators can play in more suitably preparing our students for their careers. Teaching and Learning STEM is the how-to for achieving these visions one course at a time, one semester at a time, one activity at a time. The strongest recommendation from Felder and Brent is, surprisingly, buried within the middle of the book, introduced with "If you don't take any other suggestion we offer in this book, take this one" (p. 103). The section heading is "Keep Improving Your Teaching," which applies to anyone and everyone who has contact with undergraduate STEM students.

\section{ACKNOWLEDGMENTS}

Sincere gratitude goes to Mary Lee Ledbetter for her suggestions for improving previous versions of this review.

\section{REFERENCES}

Handelsman J, Ebert-May D, Beichner R, Bruns P, Chang A, DeHaan R, Gentile J, Lauffer S, Stewart J, Tilghman SM, Wood WB (2004). Scientific teaching. Science 304, 521-522.

Handelsman J, Miller S, Pfund C (2006). Scientific Teaching, New York: Freeman Loughry ML, Ohland MW, Moore DD (2007). Development of a theory-based assessment of team member effectiveness. Educ Psychol Meas 67, 505-524

Loughry ML, Ohland MW, Woehr DJ (2014). Assessing teamwork skills for assurance of learning using CATME Team Tools. J Mark Educ 36, 5-19.

Ohland MW, Loughry ML, Woehr DJ, Bullard LG, Felder RM, Finelli CJ, Layton RA, Pomeranz HR, Schmucker DG (2012). The comprehensive assessment of team member effectiveness: development of a behaviorally anchored rating scale for self and peer evaluation. Acad Management Learn Educ 11, 609-630.

Wiggins G, McTighe J (2005). Understanding by Design, Alexandria, VA Association for Supervision and Curriculum Development.

Yale Center for Teaching and Learning (2016). Summer Institutes. www summerinstitutes.org (accessed 14 October 2016) 